of sudden increase of conductivity were iron, copper, brass, aluminium, zine and similar metals. He discovered also that the conductive effect on metallic filings, caused by a nearby electrical discharge, persists for a comparatively long period, but disappears rapidly if subjected to a shock. He obtained the required result by tapping the tube in which the filings are contained. In this way he discovered a principle which was adopted in the original Marconi system. Marconi was very grateful for the help he had received from Branly. He acknowledged this help in his first cross-Channel marconigram in 1899, which was addressed to Branly. It read as follows: "Marconi sends M. Branly his respectful compliments across the Channel this fine achievement being partly due to the remarkable researches of M. Branly.",

In 1889 Lodge showed that if two small metal spheres were arranged so that they were nearly touching and separated only by a very minute film of air, the current from a small battery was unable to pass between them. This was proved by the fact that no reading was observable when a sensitive galvanometer was placed in a circuit between them. When, however, a Leyden jar was suddenly discharged in their vicinity, the air film was broken down and they cohered, making electrical contact with one another and allowing a current to pass through the galvanometer. This experiment was deseribed in the year 1890 before the Institution of Electrical Engineers and an account of it appears in the Journal. In 1890, Prof. Branly proved the very important fact that filings could be made to cohere by an electric discharge taking place in their vicinity. $\mathrm{He}$ described his researches in "La Lumière Électrique" (May and June 1891), and he showed that metal filings .could be decohered by a slight concussion. Lodge realized the importance of this fact. He introduced modifications in the Branly coherer and improved its sensitiveness considerably.

Lodge exhibited his apparatus in 1894 before the British Association at Oxford, and received signals at a distance of 150 yards. At the time, the idea did not becur to him that this instrument might be turned to practical use for long-distance radiotelegraphy. In 1902 Branly made another coherer in the form of a tiny tripod, having steel points at the end of each leg. He stood this upon the surface of a flat plate of steel. Under normal conditions no current passed between the tripod and the plate, but in the presence of the Hertzian wave coherence took place. $\mathrm{He}$ arranged his recording apparatus in such a way as to jar the plate immediately the wave had passed, thus effecting decoherence.

Throughout the rest of his long life, Branly went steadily on with research work on wireless waves and made a number of discoveries which he communicated at various times to French scientific bodies. He also wrote a number of papers which appeared in the Comptes rendus of the Paris Academy of Sciences. Even after the outbreak of War he remained at work in Paris, but in October, yielding to the persuasion of his family, he returned to the country. He was made a Grand Officer of the Legion of Honour and received many foreign distinctions.

\section{Dr. A. G. Jacques}

IN the field of experimental cell and general physiology the name of Alfred George Jacques had become increasingly prominent during recent years. Science announces that Jacques died by drowning on February 20, 1939-and to many readers of NATURE this news, already a year old, must come with the shock of surprise and it will occasion widespread regret among experimental biologists.

Though A. G. Jacques was born in England at Sutton, Surrey, on April 18, 1896, he was educated mainly in Canada, later obtained the Ph.D. degree at Harvard, and his name rightfully attained prominence from his work at the Rockefellér Institute for Medical Research. In fruitful collaboration with Dr. W. J. V. Osterhout, Jacques' early work was devoted to problems of cell physiology, using the large vesicles of Valonia and Halicystis as experimental material. These fascinating organisms still claimed his attention until his death which, it is learned, occurred at Bermuda, where he had conducted much of his experimental work. Theoretical and experimental works mainly published under his name, in the Journal of General Physiology, present an impressive record of a career so prematurely ended.

Jacques investigated the mechanism which regulates the composition of the sap of the large vesicles which he studied-he accepted the challenge which the outstanding accumulation of inorganic salts in plant cells presents-and his name will be identified with theories of salt absorption based on the view that salts enter cells in the form of undissociated molecules. This view arose from an ingenious series of experiments, in which Jacques collaborated, which showed that certain weak electrolytes $\left(\mathrm{H}_{2} \mathrm{CO}_{3}, \mathrm{H}_{2} \mathrm{~S}\right.$, $\mathrm{NH}_{4} \mathrm{OH}$, etc.) penetrate most readily as neutral molecules, and, therefore, their entrance into the sap was controlled by the $p \mathrm{H}$ relations of sap and external solution. This novel idea was extended by Jacques in his later work to embrace the entrance of the alkali metals into cells. A steady stream of papers, both theoretical and experimental, appeared under his name. It would be idle in short space to summarize his work; neither should we declare that he had reached his final goal; but the distance he had travelled in a few years of active work is the measure of the loss which science sustains by his untimely death. The challenge of the problem to which Jacques devoted himself still remains--those who take it up where he perforce relinquished it will long recognize his worth and regret his passing.

\section{F. C. Steward.}

WE regret to announce the following deaths :

Sir James MacKenna, C.I.E., formerly agricultural adviser to the Central Government of India, and director of the Agricultural Research Institute, Pusa, on April 3, aged sixty-seven years.

Dr. Oran Raber, plant physiologist and conservationist to the U.S. Forest Service, on February 29, aged forty-seven years. 